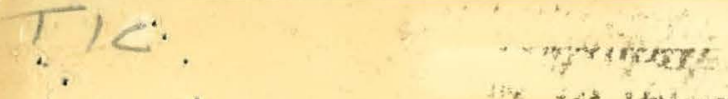

This is an informal report intended for use as a preliminary or working document

\section{GEND}

General Public Utilities - Electric Power Research Institute • U.S. Nuclear Regulatory Commission • U.S. Department of Energy

\section{FIELD MEASUREMENTS AND INTERPRETATION OF TMI-2 INSTRUMENTATION: CF-2-LT4}

\author{
J. E. Jones \\ J. T. Smith \\ M. V. Mathis
}

U.S. Department of Energy

Three Mile Island Operations Office

Under DOE Contract No. DE-AC07-76ID01570 


\section{DISCLAIMER}

This report was prepared as an account of work sponsored by an agency of the United States Government. Neither the United States Government nor any agency Thereof, nor any of their employees, makes any warranty, express or implied, or assumes any legal liability or responsibility for the accuracy, completeness, or usefulness of any information, apparatus, product, or process disclosed, or represents that its use would not infringe privately owned rights. Reference herein to any specific commercial product, process, or service by trade name, trademark, manufacturer, or otherwise does not necessarily constitute or imply its endorsement, recommendation, or favoring by the United States Government or any agency thereof. The views and opinions of authors expressed herein do not necessarily state or reflect those of the United States Government or any agency thereof. 


\section{DISCLAIMER}

Portions of this document may be illegible in electronic image products. Images are produced from the best available original document. 


\section{DISCLAIMER}

This book was prepared as an account of work sponsored by an agency of the United States Government. Neither the United States Government nor any agency thereof, nor any of their employees, makes any warranty, express or implied, or assumes any legal liability or responsibility for the accuracy, completeness, or usefulness of any information, apparatus, product or process disclosed, or represents that its use would not infringe privately owned rights. References herein to any specific commercial product, process, or service by trade name, trademark, manufacturer, or otherwise, does not necessarily constitute or imply its endorsement, recommendation, or favoring by the United States Government or any agency thereof. The views and opinions of authors expressed herein do not necessarily state or reflect those of the United States Government or any agency thereof. 


\title{
FIELD MEASUREMENTS AND INTERPRETATION OF TMI-2 INSTRUMENTATION: CF-2-LT4
}

\author{
J. E. Jones \\ J. T. Smith \\ M. V. Mathis
}

Technology for Energy Corporation

January 1982

Published on Behalf of the GEND Group

by

EG\&G Idaho, Inc.

Idaho Falls, Idaho $\mathbf{8 3 4 1 5}$

Prepared for the

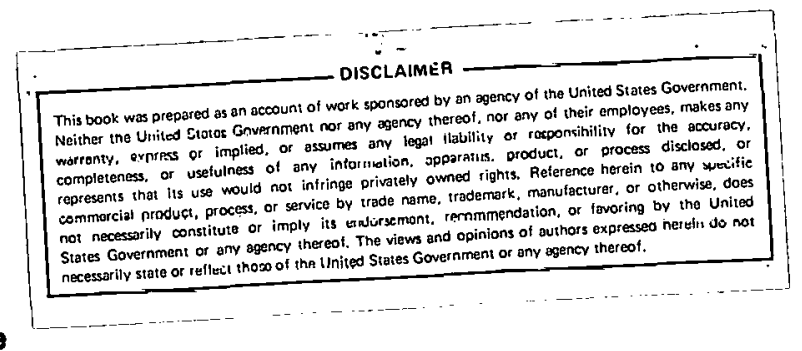

U.S. Department of Energy

Three Mile Island Operations Office

Under DOE Contract No. DE-AC07-76ID01570 


\section{THIS PAGE WAS INTENTIONALILY LEFT BLANK}




\section{TABLE OF CONTENTS}

1. INTRODUCTION

$1-1$

2. INSTRUMENT LOCATION, CABLING, AND TERMINATIONS

3. MEASUREMENT. PROCEDURES

3-1:

4. MEASUREMENTS

$4-1$

5. INTERPRETATION OF MEASUREMENTS

$5-1$

6. CONCLUSIONS

$6-1$ APPENDIX 
Table

Page

2-1 Termination Points for CF-2-LT4 Measurements 2-3

4-1 Capacitance, Impedance, and Resistance Measurements 4-6

5-1 Major AC Components on the Level Signal 5-2

5-2 Summary of TDR Measurements 5-5 


\section{LIST OF FIGURES}

Figure . Page

2-1 Composite Electrical Diagram for Core Flood Tank Level 2-2 Transmitters CF-2-LT2 and CF-2-LT4

2-2 Functional Diagram of Bailey Type BY Differential 2-4 Pressure Transmitter

4-1 Oscilloscope Traces of Level Signal 4-2

4-2 Oscilloscope Trace of 118 VAC Supply. 4-3

4-3 High Frequency Spectra of Level Signal 4-4

4-4 Low Frequency Spectra of Level Signal 4-5

4-5 TDR Trace of Level Signal Lines 4-8

4-6 TDR Trace of (+) Signal to Shield 4-9

4-7 TDR Trace of 118 VAC Lines 4-10

4-8 TDR. Trace of 118 VAC $(H)$ to Shield 4-11 


\section{Section 1}

INTRODUCTION

During and following the TMI-2 accident, a number of instruments failed or were suspected of providing erroneous readings. Because of this problem, industry concerns were focused upon the behavior of instrumentation under adverse conditions. To better understand failure mechanisms, the Technical Integration Office (TIO) contracted Technology for Energy Corporation (TEC) to perform field measurements on a set of selected TMI-2 instruments to determine in-situ operating. characteristics. For some instruments, these measurements were to be performed prior to removal (and replacement with new instruments) in order to have a cross reference with post removal observations. For other instruments, an indication of the condition of the instrument (i. e., fully operational or failed) was desired.

This report describes the measurements and results of the Core flood Tank IB level monitor CF-2-LT4. This instrument consists of a Bailey Type BY Process Computer Transmitter connected to a readout module by approximately 500 feet of cable through a penetration junction and an instrument mounting junction. The status of this instrument is uncertain, but it was producing a reasonable output reading which implied it had not failed. As a result, measurements on this instrument were designed to determine if it was properly functioning. 
Section 2

INSTRUMENT LOCATION, CABLING, AND TERMINATIONS

A review of appropriate drawings from Bailey Meter Company and Burns \& Roe (itemized in the Appendix in the measurement procedure, pages A-5 and $A-6$ ) resulted in the composite electrical diagram shown in Figure 2-1. From this information, Table 2-1 gives a list of the appropriate termination points for performing measurements in Control Cabinet 156. Also noted in Figure 2-1 are the cable lengths pulled during instrument installation and lengths after trimming between each termination and/or junction point.

The level sensing assembly is a Bailey Type BY which consists of a differential pressure LVDT, temperature compensation, and calibration adjustment for conversion of pressure difference to level. This instrument has a normal range of 0-14 feet, producing an output of -10 to +10 volts. The functional diagram of the unit is shown in Figure 2-2.

Since measurements were being made in Control Cabinet 156, the effect of the readout meter (attached to the signal line) was present on the observed instrument response. However, since this readout was located outside containment, it did not experience severe operating environments, and thus was not considered to have failed. 


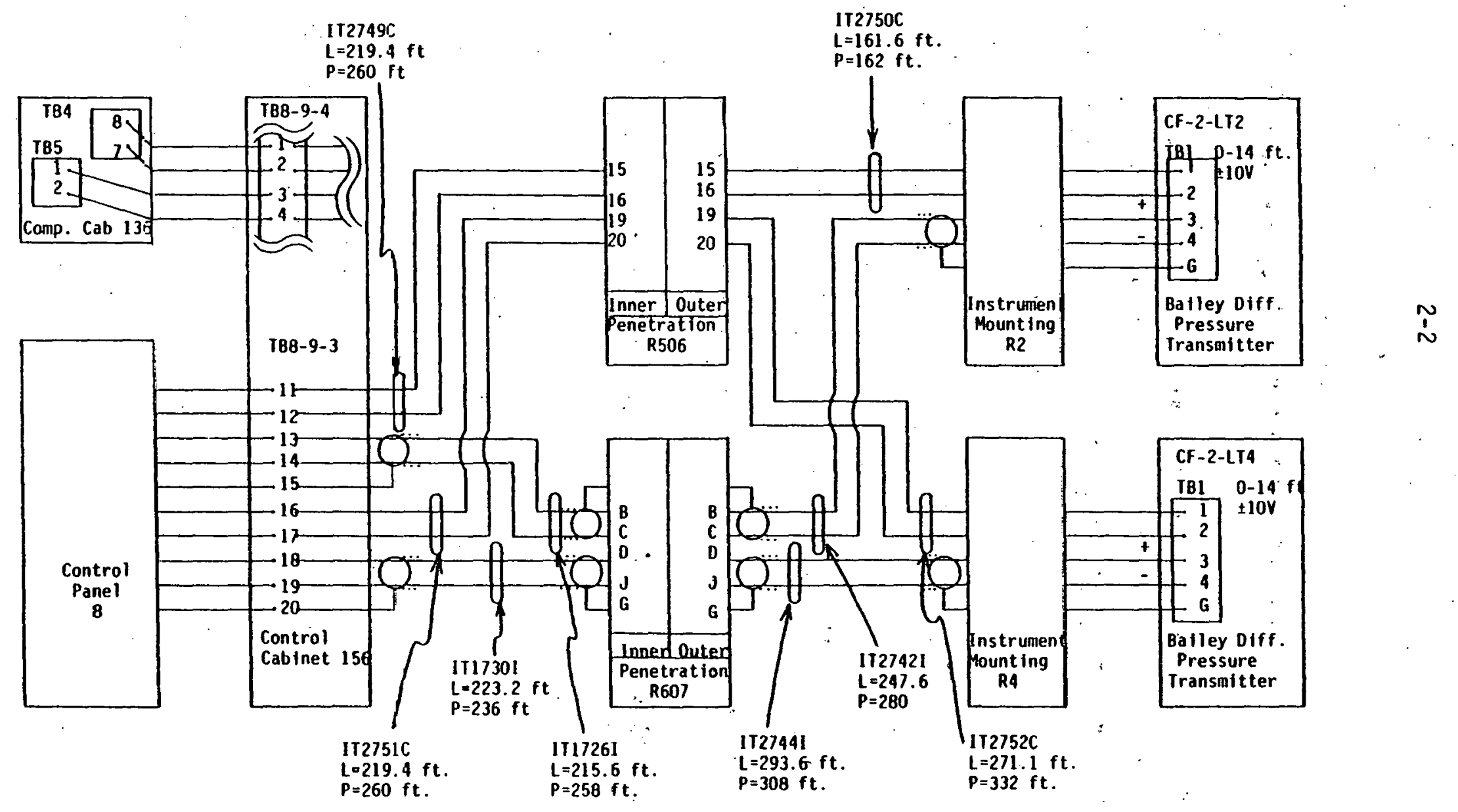

Figure 2-1. Composite Electrical Diagram for Core Flood Tank Level Transmitters CF-2-LT2 and CF-2-LT4. 


$$
2-3
$$

Table 2-1

TERMINATION POINTS FOR CF-2-LT4 MEASUREMENTS

\begin{tabular}{lc} 
Signal & Cabinet 156 Identification ${ }^{*}$ \\
\hline +Signal & TB8-9-3/19 \\
-Signal & TB8-9-3/18 \\
Shield & TB8-9-3/20 \\
118 VAC (H) & TB8-9-3/16 \\
118 VAC (L) & TB8-9-3/17 \\
&
\end{tabular}




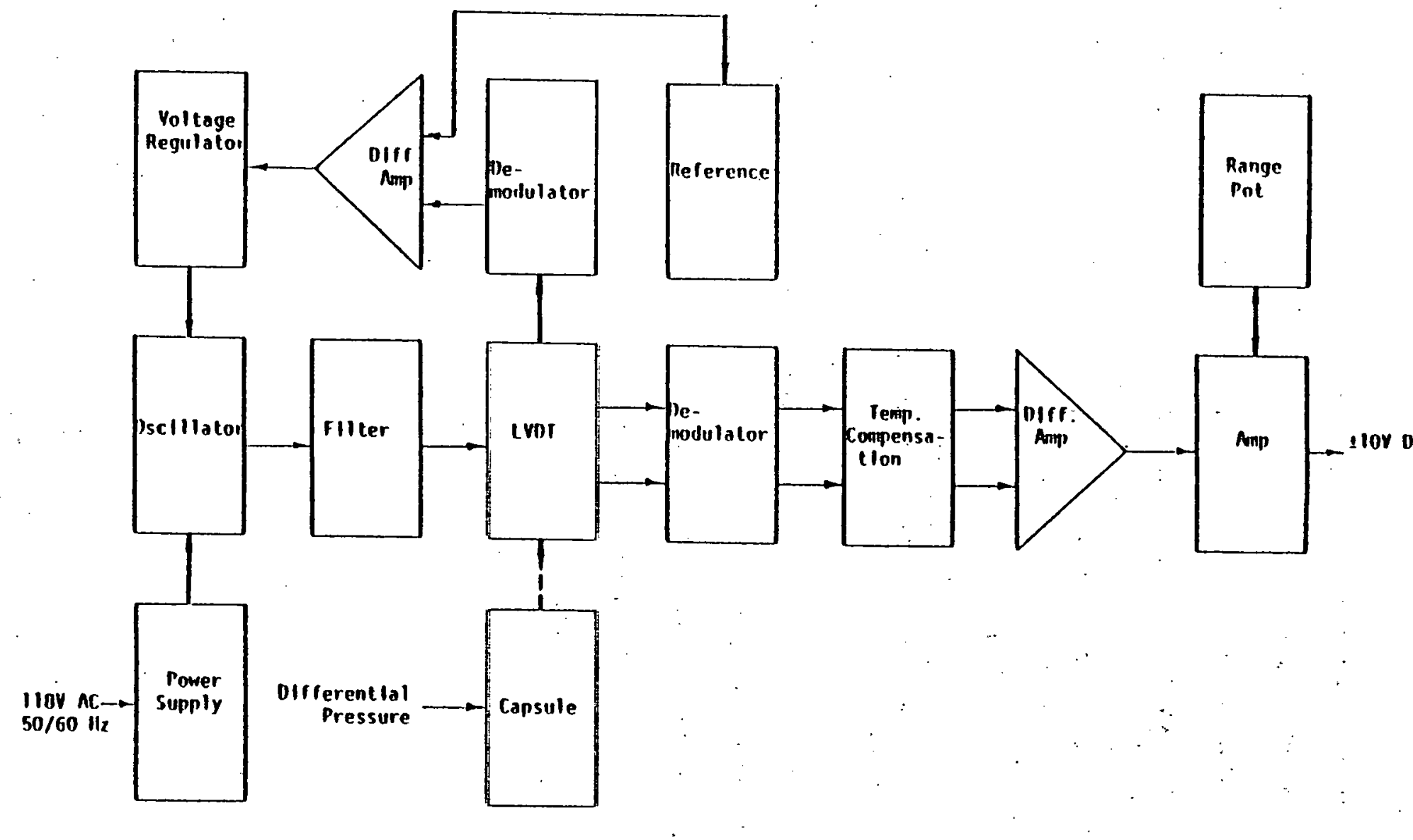

Figure 2-2. Functional Diagram of Bailey Type BY Differential Pressure Transmitter. 
Section 3

PREPARATION OF MEASUREMENT PROCEDURES

As a result of generating the composite electrical diagram and from a review of the Bailey Meter Product Instruction E21-17 Manual, the major types of measurements to be performed were identified as:

1. Determine as-found condition of level indication and record signal output.

2. Perform passive measurements (i.e., passively monitor signals) on each electrical connection consisting of time domain waveforms, very-high frequency spectrum analysis (i.e., $\mathrm{MHz}$ region), and frequency spectra below $100 \mathrm{kHz}$.

3. Perform resistance, capacitance, impedance, and Time Doma in Reflectometry (TDR) active measurements (i.e., actively introducing a test signal).

These measurements were designed to verify the operation of the Readout Module and the power supplies, but the focus of the measurement was on the level measurement assembly, cabling, and terminations/connections to the assembly. The Appendix contains the detailed procedure which was followed during the measurement program, and a summary of measurements is presented in the next section. 
Section 4

MEASUREMENTS

Since the output of CF-2-LT4 was designed to cover the range of -10 to +10 volts, the signal could be directly measured without amplification. Before performing measurements, the readout of CF-2-LT4 indicated 11 feet for the core flood tank level. The level indication signal was then recorded for approximately 10 minutes on an FM recorder and the voltage outputs measured (with a DVM). The output of the level signal was 5.72 VDC, and the power supply was 116 VAC.

The next measurements consisted of photographing the output waveforms of the level signal and line voltage from a storage oscilloscope. Figures 4-1 and 4-2 show the results of these time trace measurements. ATong with the time traces, both high and low frequency spectra (frequency domain) were taken of the level signal. Figure 4-3 shows the measured spectra over both a $6 \mathrm{MHz}$ and $500 \mathrm{kHz}$ bandwidth, while Figure 4-4 shows spectra over both a $100 \mathrm{kHz}$ and $1 \mathrm{kHz}$ range.

Following the frequency spectra measurements, electrical calibration was performed on the CF-2-LT4 readout module by a TMI technician. No significant adjustments were noted during this calibration. After electrical calibration, power was removed from CF-2-LT4. The test fixture was removed and all signal lines from cables IT1730I and IT2751IC to cabinet 156 were disconnected.

A series of active measurements (i.e., actively introducing a test signal into the circuit) was then performed. Table 4-1 shows the 


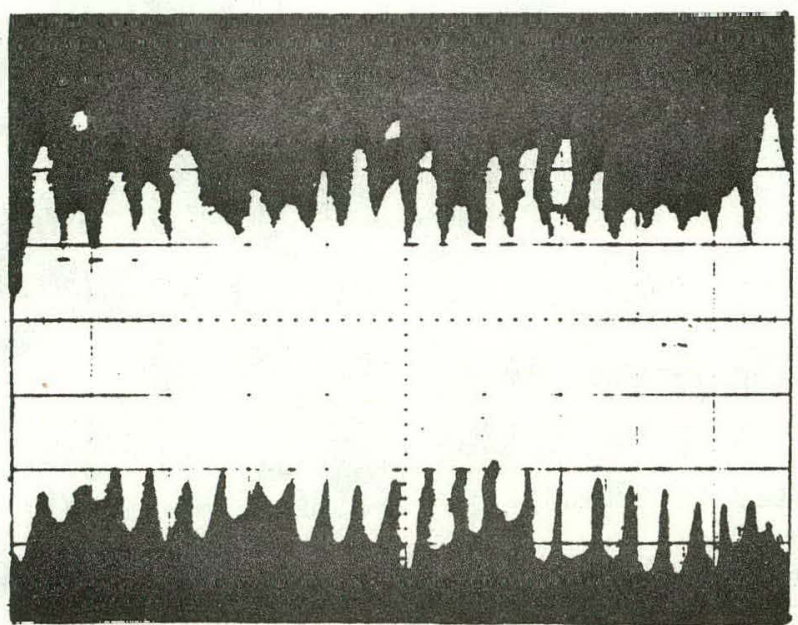

Photo 109-1

Time $-2 \mathrm{msec} / \mathrm{div}$

Gain - $10 \mathrm{mV} / \mathrm{div}$

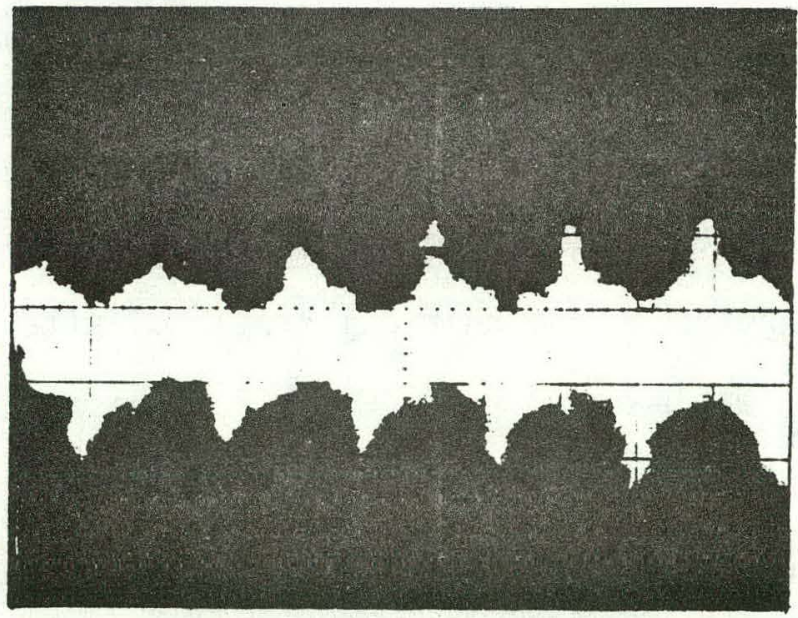

Photo 109-2

Time $-0.5 \mathrm{msec} / \mathrm{div}$

Gain - $20 \mathrm{mV} / \mathrm{div}$

Figure 4-1. Oscilloscope Traces of Level Signal. 
4-3

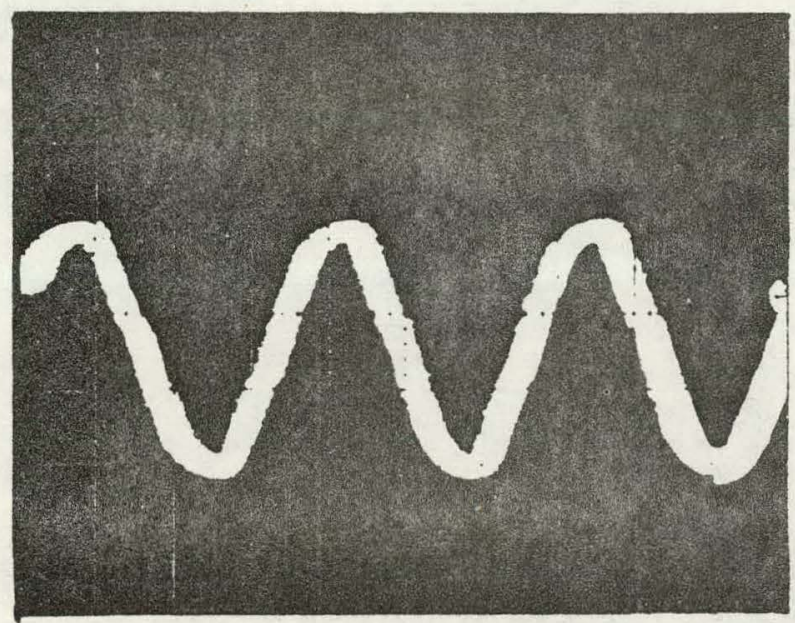

Photo 109-3

Time $-0.5 \mathrm{msec} / \mathrm{div}$

Gain - $10 \mathrm{~V} / \mathrm{div}$

Figure 4-2. Oscilloscope Trace of 118 VAC Supply. 


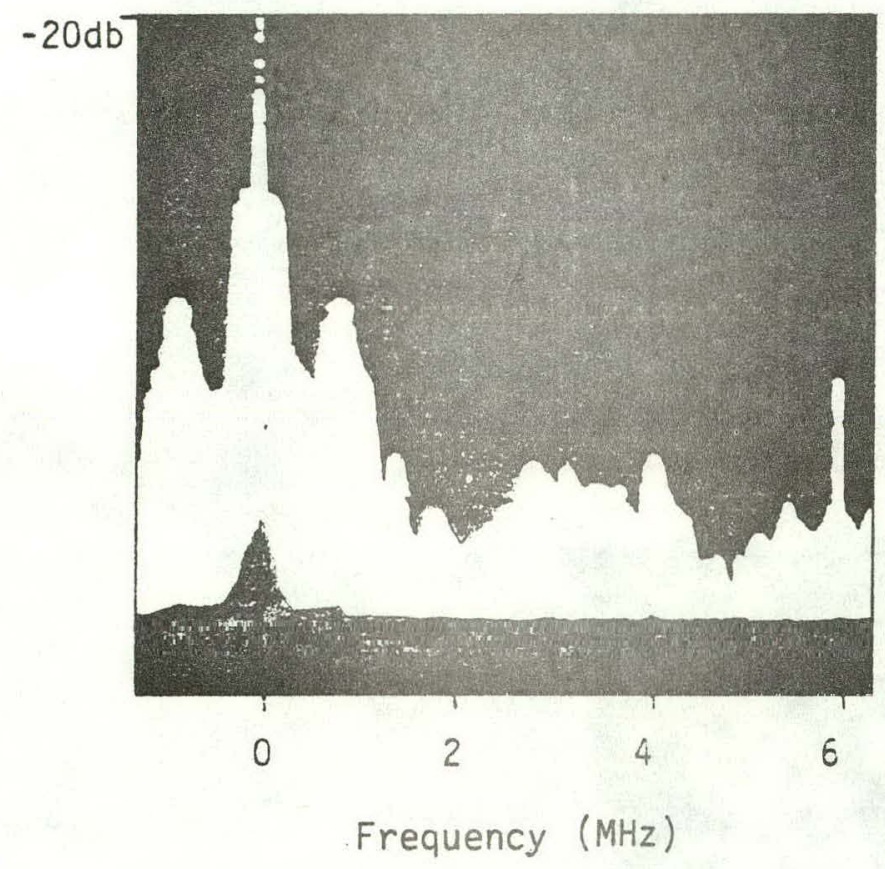

Photo $109-4$

$B W-3 \mathrm{KHz}$

Scan width - $1 \mathrm{MHz} / \mathrm{div}$

Scan time - $1 \mathrm{sec} / \mathrm{div}$

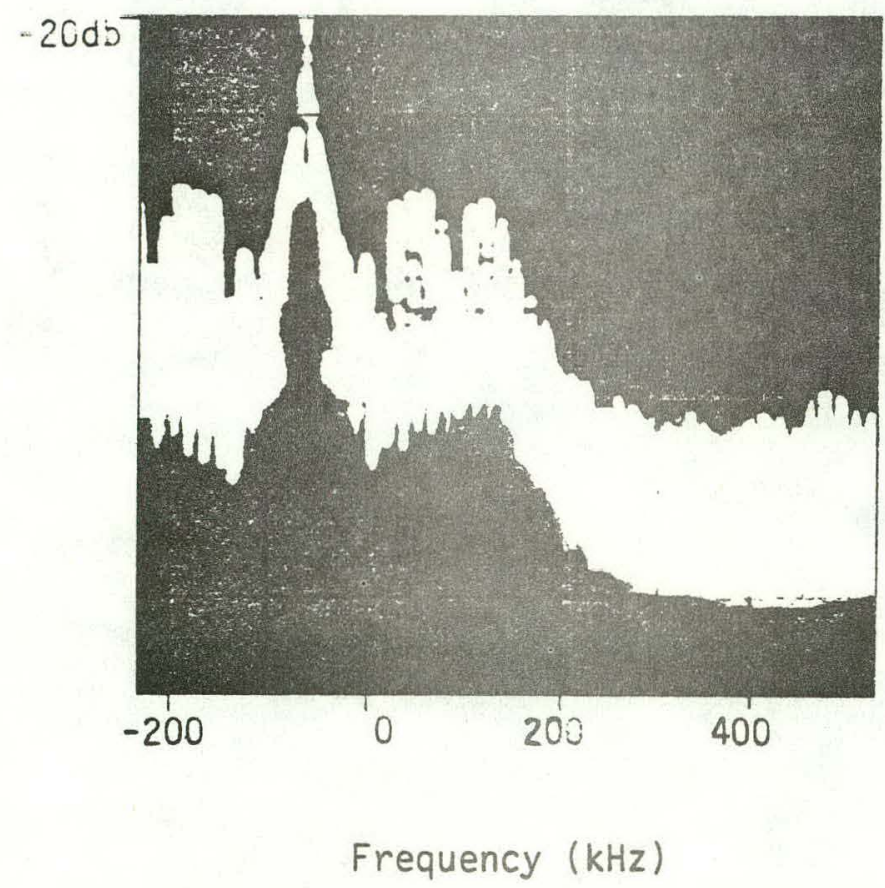

Photo $109-5$

$\mathrm{BW}-3 \mathrm{KHz}$

Scan width - $100 \mathrm{KHz} /$ div

Scan time - $1 \mathrm{sec} / \mathrm{div}$

Figure 4-3. High Frequency Spectra of Level Signal. 
0.00697 2NS

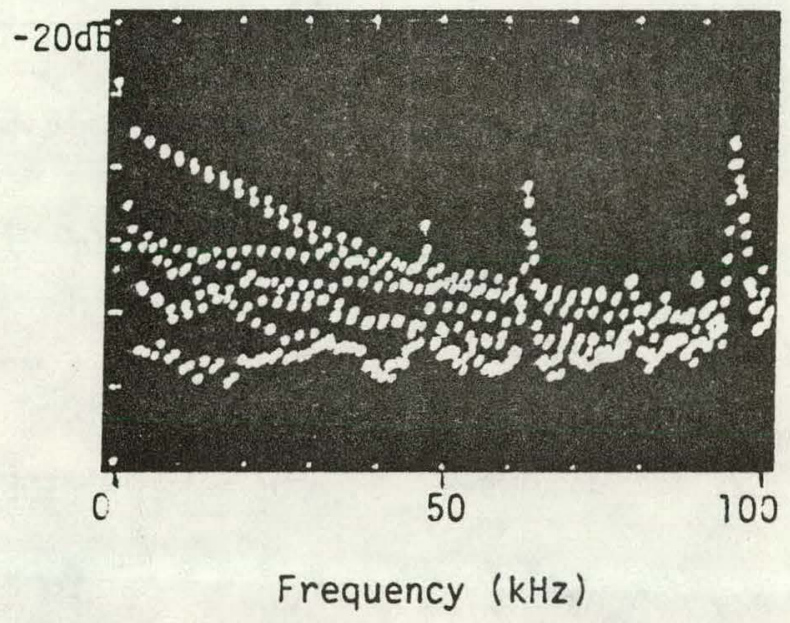

Photo - 109-6

$100 \mathrm{KHz}$ Range

0.000478 RMS

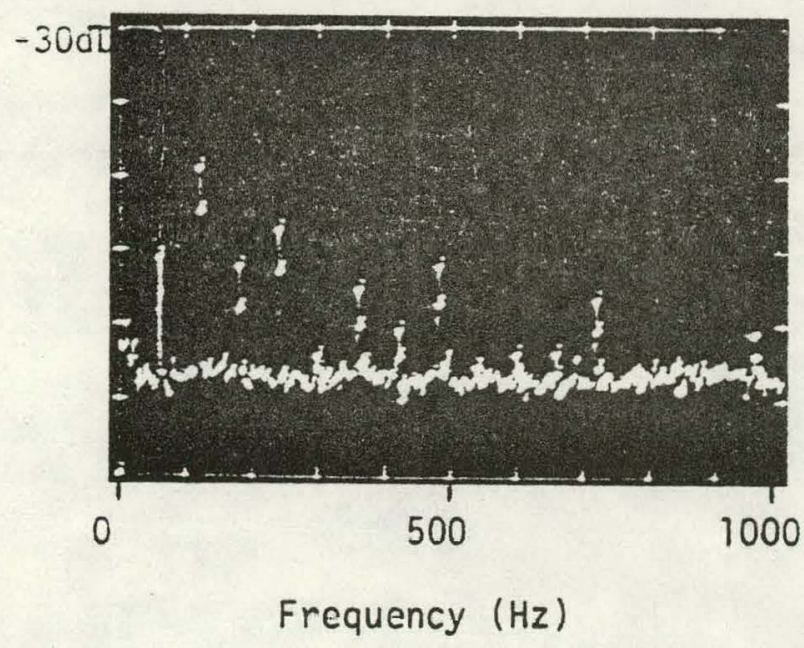

Photo 109-7

$1 \mathrm{KHz}$ Range

Figure 4-4. Low Frequency Spectra of Level Signal. 
Table 4-1

CAPACITANCE, IMPEDANCE, AND RESISTANCE MEASUREMENTS

\begin{tabular}{|c|c|c|c|c|c|c|c|}
\hline \multirow[b]{2}{*}{ Signat } & \multicolumn{3}{|c|}{ Capacitance $(\mathrm{nF})^{\star}$} & \multicolumn{3}{|c|}{ Impedance (ohms) } & \multirow{2}{*}{$\begin{array}{l}\text { Resistange } \\
\text { (ohms) }\end{array}$} \\
\hline & $100 \mathrm{~Hz}$ & $1 \mathrm{kHz}$ & $100 \mathrm{kHz}$ & $100 \mathrm{~Hz}$ & $1 \mathrm{kHz}$ & $100 \mathrm{kHz}$ & \\
\hline $\begin{array}{l}\text { +Signal } \\
\text {-Signal }\end{array}$ & 23 & 18 & 12 & $4.4 K$ & $3.2 \mathrm{~K}$ & 124 & $7.1 \mathrm{~K}(8.8 \mathrm{~K})$ \\
\hline $\begin{array}{c}\text { +Signal } \\
\text { Shield }\end{array}$ & 50 & 42 & 34 & $\mathrm{OF}^{+}$ & $3.6 \mathrm{~K}$ & 48 & $O F$ \\
\hline $\begin{array}{r}\text {-Signal } \\
\text { Shield }\end{array}$ & 50 & 44 & 37 & OF & $3.5 \mathrm{~K}$ & 44 & OF \\
\hline $\begin{array}{l}118 \text { VAC }(H) \\
118 \text { VAC (L) }\end{array}$ & -120 & 17 & 52 & $12 \mathrm{~K}$ & $9 \mathrm{~K}$ & 30 & $105(105)$ \\
\hline $\begin{array}{l}118 \text { VAC }(H) \\
\text {-Signal }\end{array}$ & - & .2 & 8.7 & OF & OF & 109 & OF \\
\hline $\begin{array}{l}118 \text { VAC (H) } \\
\text { Shield }\end{array}$ & -- & .2 & 28 & OF & OF & 66 & OF \\
\hline
\end{tabular}

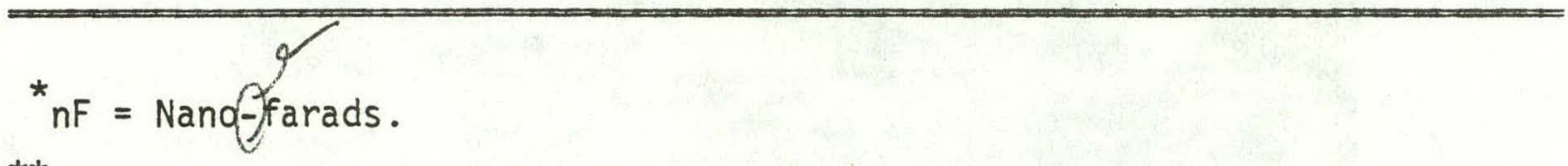

** Values in parentheses are reverse polarity values.

${ }^{\dagger} \mathrm{OF}$ indicates overflow condition. 
results of capacitance, impedance, and $D C$ resistance measurements on some of the field cable lines (see Appendix page A-12 for a complete set). A set, of TDR measurements were taken on the signal lines to determine possible cable defects. These TDR traces are shown in Figures $4-5$ to $4-8$. 
STRIP CHART 109-1

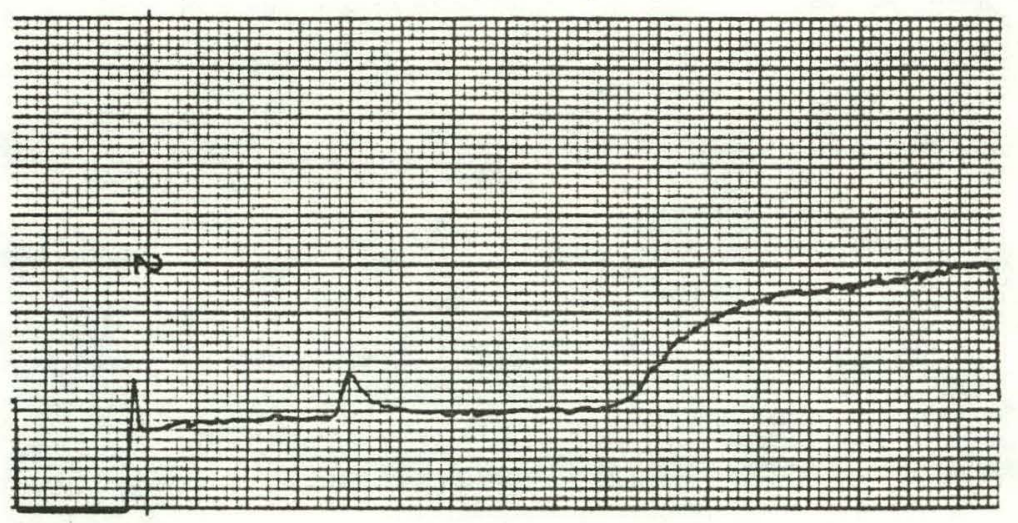

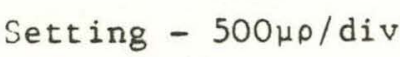

Range - $52.6 \mathrm{ft} / \mathrm{div}$

Sensitivity -0.25

Filter - $5 \mathrm{~Hz}$

Cable dielectric - other

Figure 4-5. TDR Trace of Level Signal Lines 
STRIP CHART $109-2$

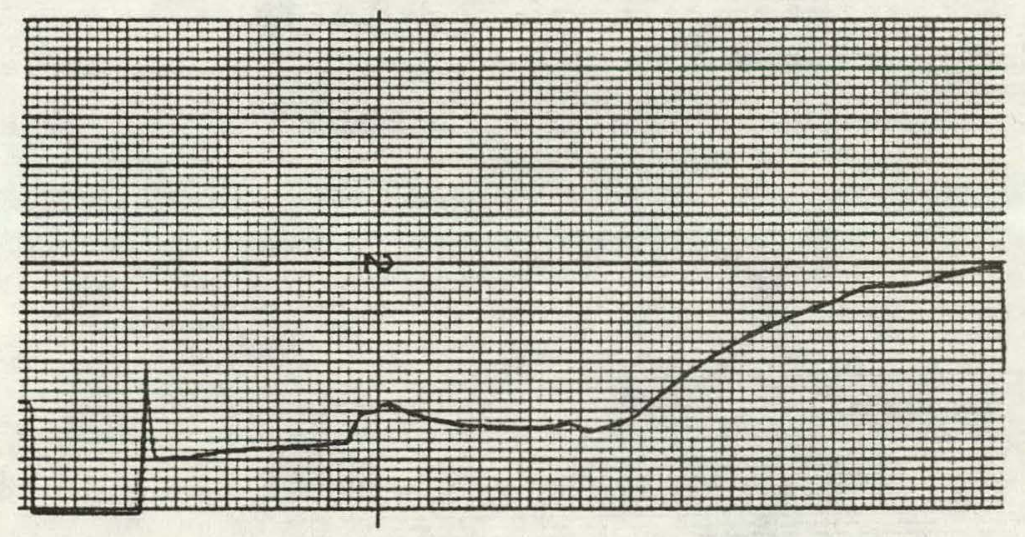

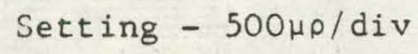
Range - $52.6 \mathrm{ft} / \mathrm{div}$ Sensitivity -0.25

Filter $-5 \mathrm{~Hz}$ Cable dielectric - other

rigure 4-6. IDR Trace of (+) Signal to Shield 
STRIP CHART $109-3 \& 4$

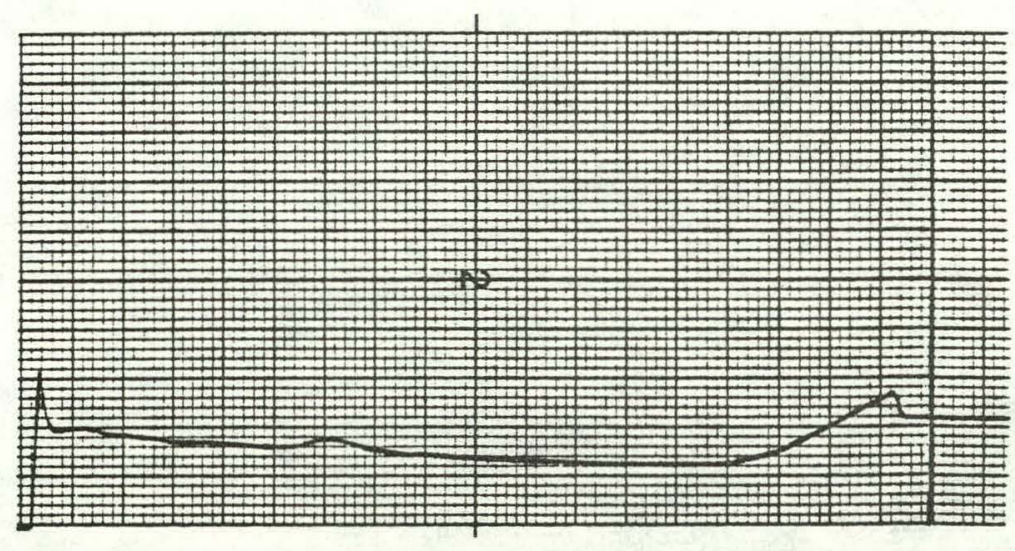

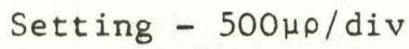

Range $-52.6 \mathrm{ft} / \mathrm{div}$

Sensitivity -0.25

Filter $-5 \mathrm{~Hz}$

Cable dielectric - other

2nd plot begins@500 ft

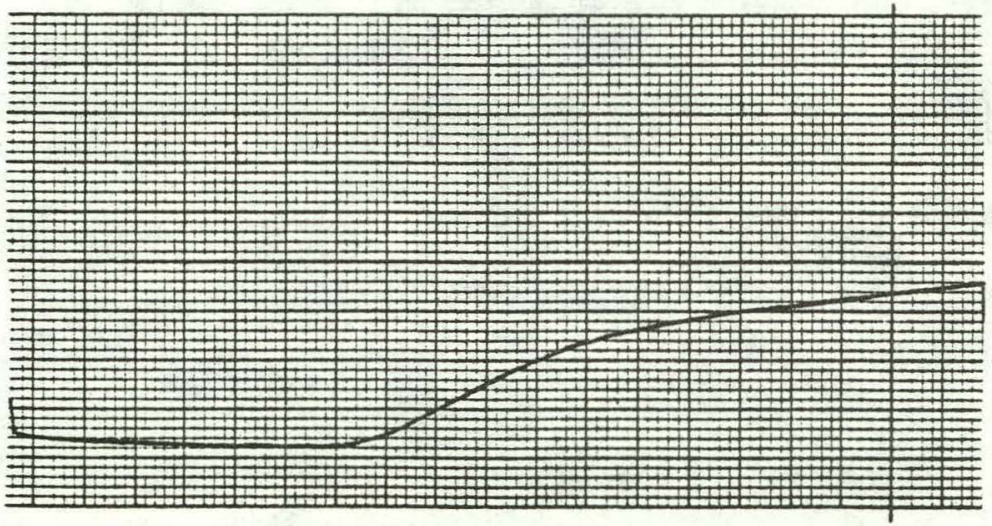

Figure 4-7. TDR Trace of 118 VAC Lines 


\section{4-11}

STRIP CHART $109-5,6$, \& 7

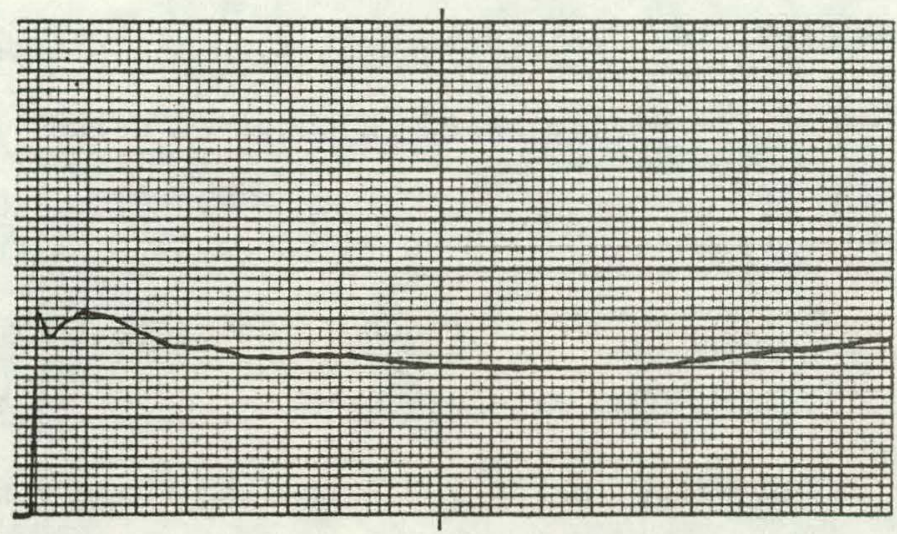

Setting - 500up/div

Range $-52.6 \mathrm{ft} / \mathrm{div}$

Sensitivity - 0.25

Filter $-5 \mathrm{~Hz}$

Cable dielectric - other

2nd plot begins@500 ft

3rd plot begins@1000 ft
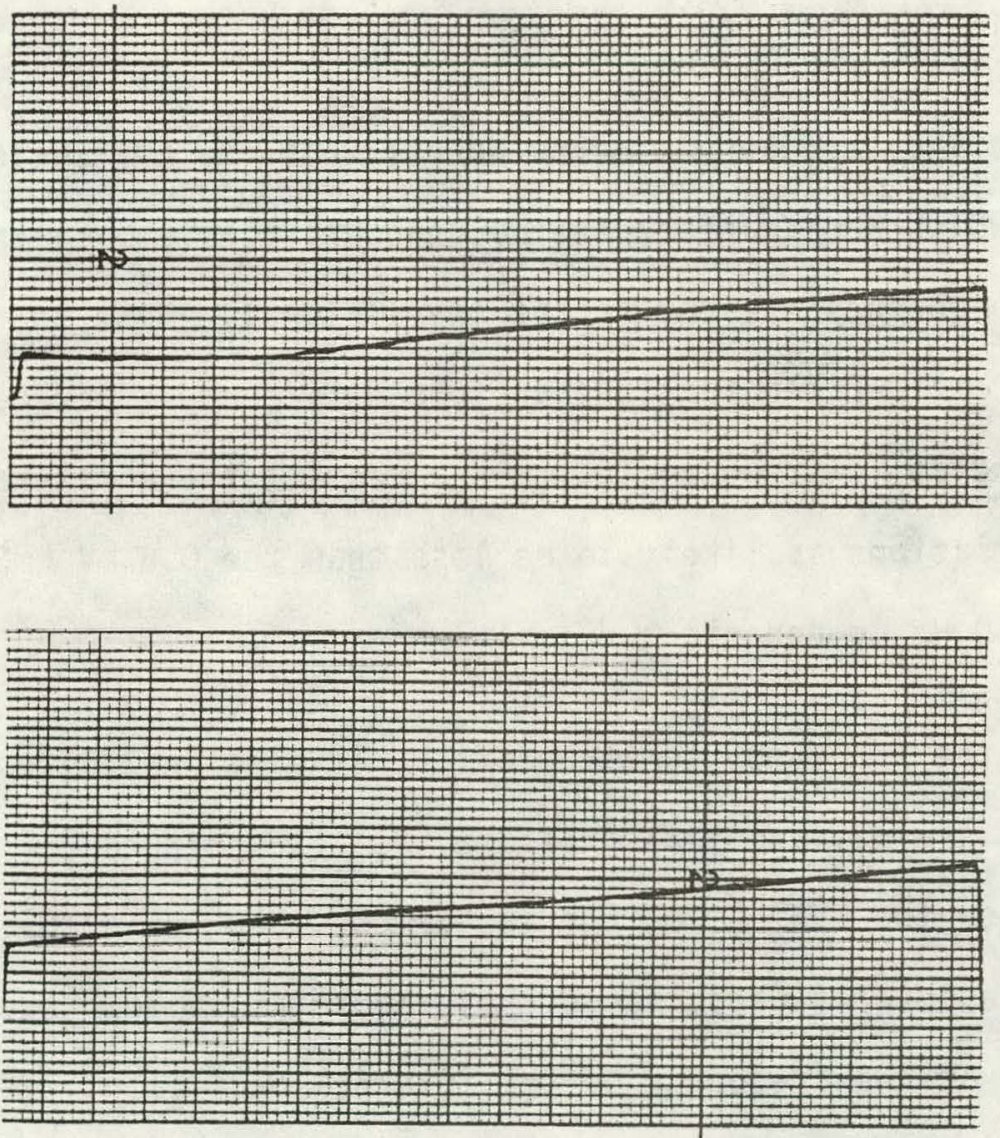

Figure 4-8. TDR Trace of $118 \operatorname{VAC}(H)$ to Shield 
Section 5

\section{INTERPRETATION OF MEASUREMENTS}

This section presents a summary of the interpretation of the measurements taken on CF-2-PT4. This interpretation is intended to indicate the condition of the device based on observed data.

Since this device varies from -10 to +10 volts for a 0 to 14 foot level range, the observation of 11 foot level readout indicates that the voltage should be 5.71 volts. The measured value of 5.72 volts matches within $1 \%$ of this expected value, which indicates the readout meter is correctly calibrated. The 116 VAC value on the power supply line is also well within a normal operating range.

The time traces and frequency spectra do not indicate any serious contamination which would affect the DC readout. Table 5-1 lists the low level AC components present on the level signal. Note that even though up to $60 \mathrm{mV}$ P-P fluctuations are present, readout devices normally respond at low frequencies. As a result, the worst-case effect of these AC variations is likely to be less than the $0.5 \mathrm{mV}$ RMS value given for the $60 \mathrm{~Hz}$ components.

One feature of the frequency spectrum of the level signal gives an indication that the differential pressure LVDT (see Figure 2-2) is operating. Since the LVDT AC output is "demodulated" by a full-wave rectifier and Resistance-Capacitance (RC) smoothing, a low level ripple must be present at the frequency of the internal oscillator. The oscillator for this type device operates at 1000 hertz and the component 


\section{$5-2$}

Table 5-1

MAJOR AC COMPONENTS ON THE LEVEL SIGNAL

$60 \mathrm{~Hz}$ and harmonics

$0.5 \mathrm{mV}$ RMS

$1 \mathrm{kHz}$ and harmonics.

$6 \mathrm{mV}$ RMS

$48 \mathrm{kHz}$

$<1 \mathrm{miV}$ RMS

$64 \mathrm{kHz}$

$<1 \mathrm{mV}$ RMS

$96 \mathrm{kHz}$

$1 \mathrm{mV}$ RMS

$150 \mathrm{kHz}$ (broadband)

<1 mV RMS

Total Spectrum

$60 \mathrm{mV}$ P-P 
values of the $R C$ smoothing circuit $(R=100 k$ ohms, $C=0.68 \mu F)$ would produce a ripple factor (fraction of AC RMS fluctuations) of 0.001 . With the device producing a five volt output (15 volts above base output of $-10 \mathrm{~V})$, the expected RMS ripple would be approximately $5 \mathrm{mV}(15 \mathrm{mV})$. From Table 5-1, this AC ripple value was measured to be $6 \mathrm{mV}$, which is in close agreement. Also, the reduction in amplitude of the higher harmonics (see Figure 4-4) is consistent with the expected attenuation of a rectified signal.

The capacitance, impedance, and resistance data given in Table 4-1 is difficult to quantitatively interpret, but qualitative results are possible. Most of the data indicates very low effective capacitance values, which would be expected from the amplifier section of the transmitter. However, the 118 VAC $(H)$ to 118 VAC $(L)$ measurement passes through the primary of a transformer. This creates an inductance which appears as negative capacitance at the 100 hertz measurement.

The presence of a 10,000 ohm resistor in the transmitter amplifier and the absence of other direct electrical paths indicates that a resistance measurement near this value should be obtained. The measured values for the level signal were 7100 and 8800 ohms for two polarities. The variation would be caused by active electrical components, and the values are of the magnitudes expected. Since the expected responses are present, there is no obvious indication of instrumentation degradation from these measurements. 


$$
5-4
$$

The results of TDR measurements performed on the cable (shown in Figures 4-5 to 4-7) are summarized in Table 5-2. Note that the lengths identified in the table are only approximate, since no calibration of the cable resistance and material composition was performed on the TDR instrument. Some junction points were not identified by these measurements, but no indication of cabling problems is present in this data. 
$5-5$

Table 5-2

SUMMARY OF TDR MEASUREMENTS

\begin{tabular}{|c|c|c|c|}
\hline $\begin{array}{l}\text { Signal } \\
\text { Lines }\end{array}$ & $\begin{array}{l}\text { Distance } \\
(\mathrm{ft})\end{array}$ & Description $^{\star \star}$ & Probable Cause \\
\hline $\begin{array}{l}\text { +Signal. } \\
\text {-Signal }\end{array}$ & $\begin{array}{l}211 \\
489\end{array}$ & $\begin{array}{l}\text { Point } R \text { increase } \\
\text { Large } R \text { increase }\end{array}$ & $\begin{array}{l}\text { Penetration } \cdot R 607 \\
\text { Electronics }\end{array}$ \\
\hline $\begin{array}{l}\text { +Signal } \\
\text { Shield }\end{array}$ & $\begin{array}{l}200 \\
416 \\
464\end{array}$ & $\begin{array}{l}\text { Point } R \text { increase } \\
\text { Point } R \text { small increase } \\
\text { Large } R \text { increase }\end{array}$ & $\begin{array}{l}\text { Penetration } R 607 \\
\text { Terminal block } \\
\text { Electronics }\end{array}$ \\
\hline $\begin{array}{l}118 \text { VAC }(H) \\
118 \text { VAC }(L)\end{array}$ & $\begin{array}{l}263 \\
716\end{array}$ & $\begin{array}{l}\text { Point } R \text { increase } \\
\text { Large } R \text { increase }\end{array}$ & $\begin{array}{l}\text { Penetration } \mathrm{R} 607 \\
\text { Electronics }\end{array}$ \\
\hline
\end{tabular}

Note: Distances are not calibrated due to lack of prior information on the cable type which prevented calibration tests.

* TDR to terminal block test cable ( $15 \mathrm{ft}$ ) not included in distance. ${ }^{\star \star} R$ is the abbreviation for resistance. 
Section 6

CONCLUSIONS

Based on the measurements, data reduction, and circuit analys is of. CF-2-LT4, there is no indication of degradation of the instrument. The only significant contamination present in the pressure signal that appeared to be abnormal was the $96 \mathrm{kHz}$ component. However, the amplitude of this signal was relatively low and, from other measurements performed at TMI, this low-level $96 \mathrm{kHz}$ component is probably due to a widespread $16 \mathrm{kHz}$ (with harmonics) signal found in various circuits. In addition to the observation of no abnormal characteristics of the instrument, the low level oscillator ripple on the level signal indicates that the LVDT is working. Therefore; it appears that CF-2-LT4 is operating correctly, but these measurements could not determine if it is calibrated. 
APPENDIX

ORIGINAL FIELD PROCEDURES AND

DATA SHEETS FOR CF-2-LT4 


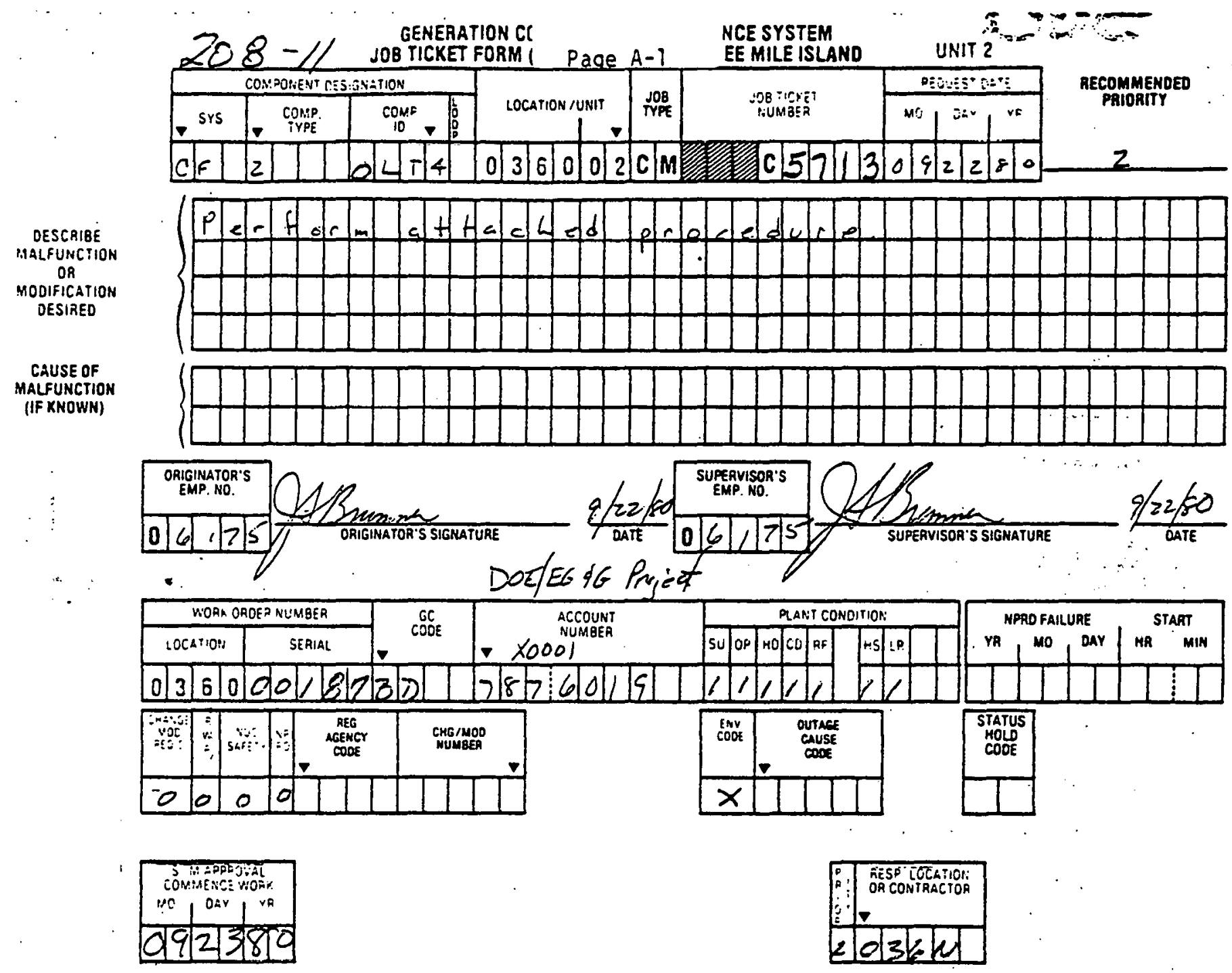

Comnly with the Provisions

Set forth in tip 1002 and

Umits and Precautions: Met Ed Safeity Mianual.

a) Personnel

D) Equipment

c) Environment

d) Nuclear

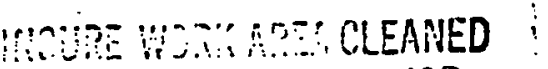

Post Maintenance Testing required and Acceptance Criteria. 


\section{REVIEW - CLASSIrILAgE A-2 RUUING CONTROL FORM}

\section{JOB TICKET NUMBER C $\quad 5713$}

1. Does work represent a change or modification to an existing system or component? If yes, an approved change modification is required per AP 1021.

C/M No.

NA

2a. Does work requires an RWP?

$2 \mathrm{~b}$. Is an approved procedure required to minimize personnel exposure?

3a. Is work on a QC component as defined in GP 1008?

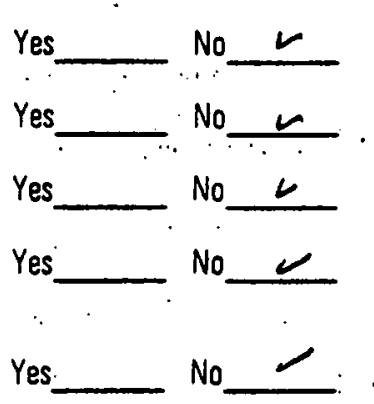

4. Agreement that a PORC reviewed, Superintendent approved procedure is not required for this work because it has no effect on nuclear safety. IApplies only if $3 a$ is Yes and $3 b$ is Nol.'

b. If $3 a$ is yes does work have an effect on Nuclear Safety? If $3 b$ is yes, PORC reviewed Superintendent approved procedure must be used.

$\therefore$. . . .

Yes $\mathrm{No}$

5a. Is the system on the Environmental Impact list in AP 1026?

5b. If $5 a$ is YES, is an approved procedure required to limit environmental impact?

Yes No

6. Agreement that $5 b$ is No. (Required only if $5 a$ is. Yesi. .

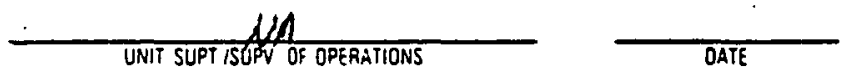

7. Plant status or prerequisite conditions required for work. (Operating and/or shutdown)

8. OC Dept. review, if required in item No. 3 .

\section{NA} OC SUPEAVISOA
DATE

9. Does work require code inspector to be notified?

10. Supervisor of Majotenance agaroyal to commence work: -

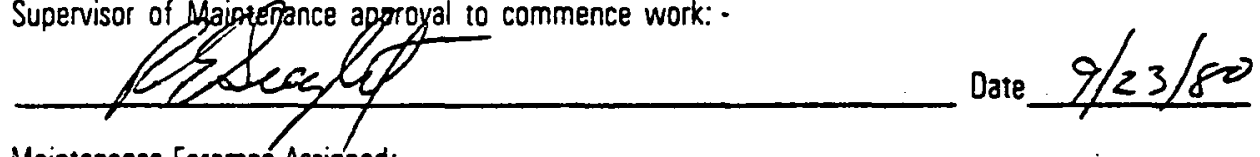

11. Maintenance Foreman Assigned:

12. Code inspector Notified. Name:

13. Shif foreman's approval to commence work: Initial if Shift Foreman signarure is not required.
Date Date 


\section{WORK 1 Page A-3 :DURE}

Maintenance Procedure Format and Approval

Unit No

2.

This form outlines the format and acts as a cover sheet for a maintenance procedure. Due to the limited size of the form, additional pages may be attached as required. Work Request procedure AP 1016 Section 6 should be used as a guide in preparing the maintenance procedure.

1. Procedure Title \& No.:

Sensor/Cable measarements on CF-Z-LTH

2 Purpose: To determine signal characteristics on CF-Z-LT4. $\therefore$

3. Description of system or component to be worked on.

$$
C F-2-\angle T 4
$$

4. References:

$$
\text { See atfached. }
$$

5. Special Tools, and Materials required.

$$
\text { See attuched }
$$

6. Detailed Procedure (attach additional pages as required)

see attachod

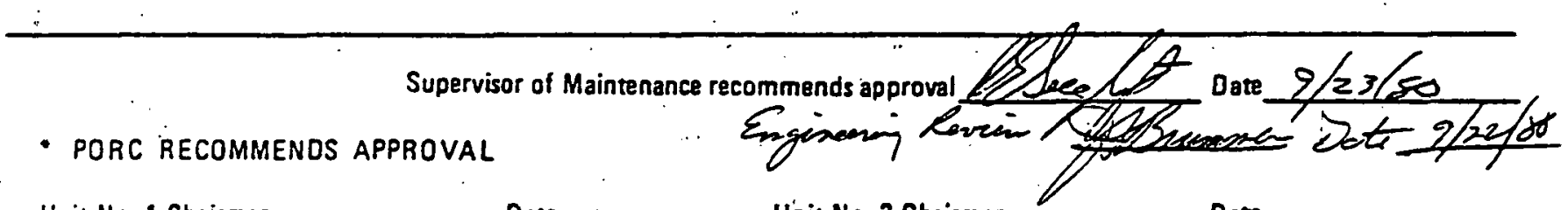

Unit No. 1 Chairman Date Unit No. 2 Chairman Date

: UNIT SUPERINTENDENT APPROVAL

Unit No. 1. Date Unit No. 2 Date

- Standing Procedure

$$
\text { Supervisor of QC }
$$$$
\because
$$

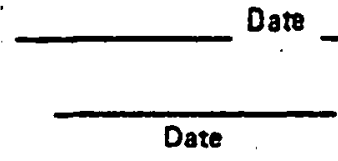

- Núle. These approvals required only on Nuclear Safety Related/Radiation work permit jobe. 


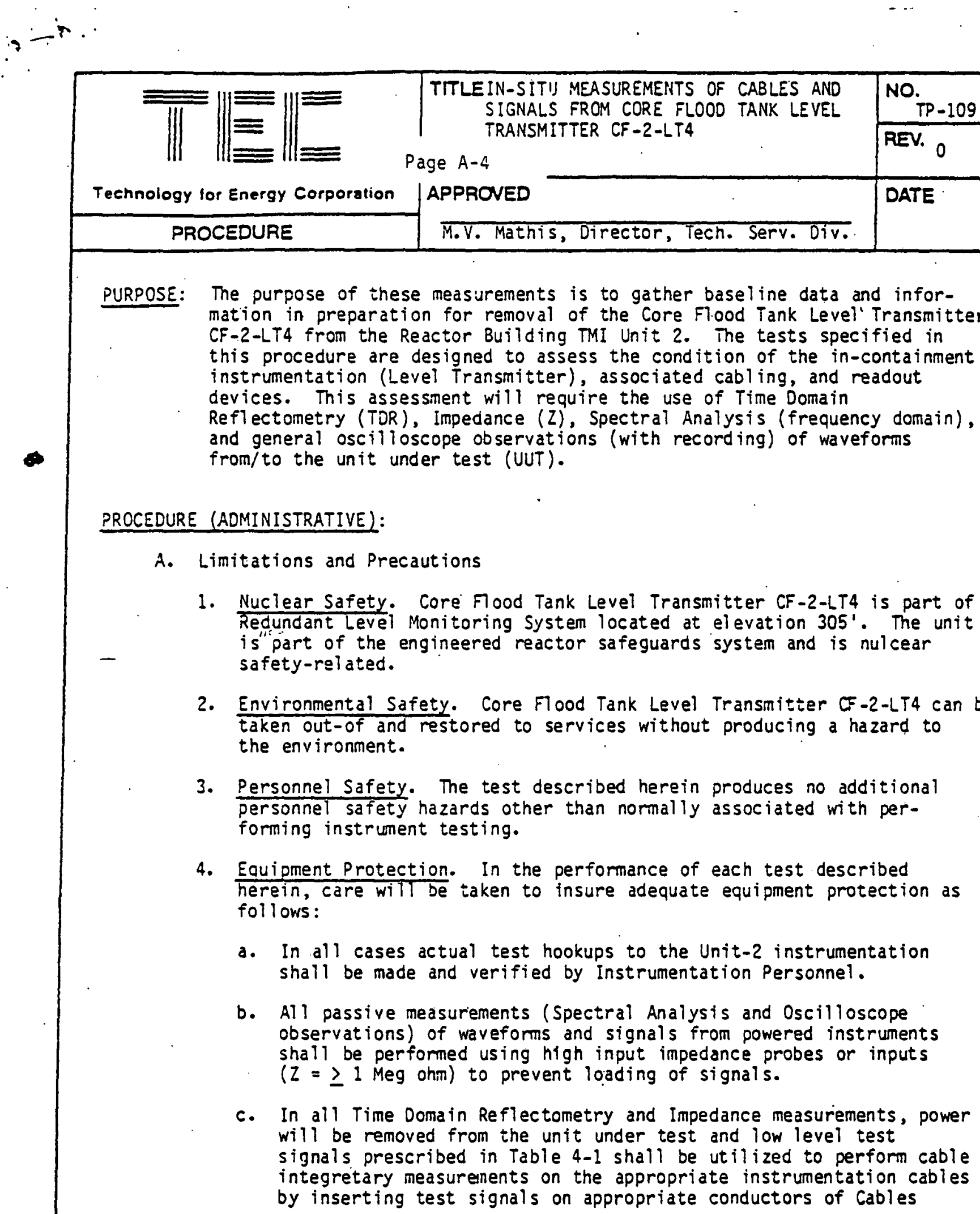




\section{Page $A-5$ \\ IN-SITU MEASUREMENTS OF CABLES. AND SIGNALS FROM CORE FLOOO TANK LEVEL TRANSMITTER CF-2-LT4}

NO. $T P-109$

FE.

IT1730I and IT2751C (Teminations shall be removed) and replaced on TB 8-9-3 of Cabinet 156).

Table 4-1 Active Measurements

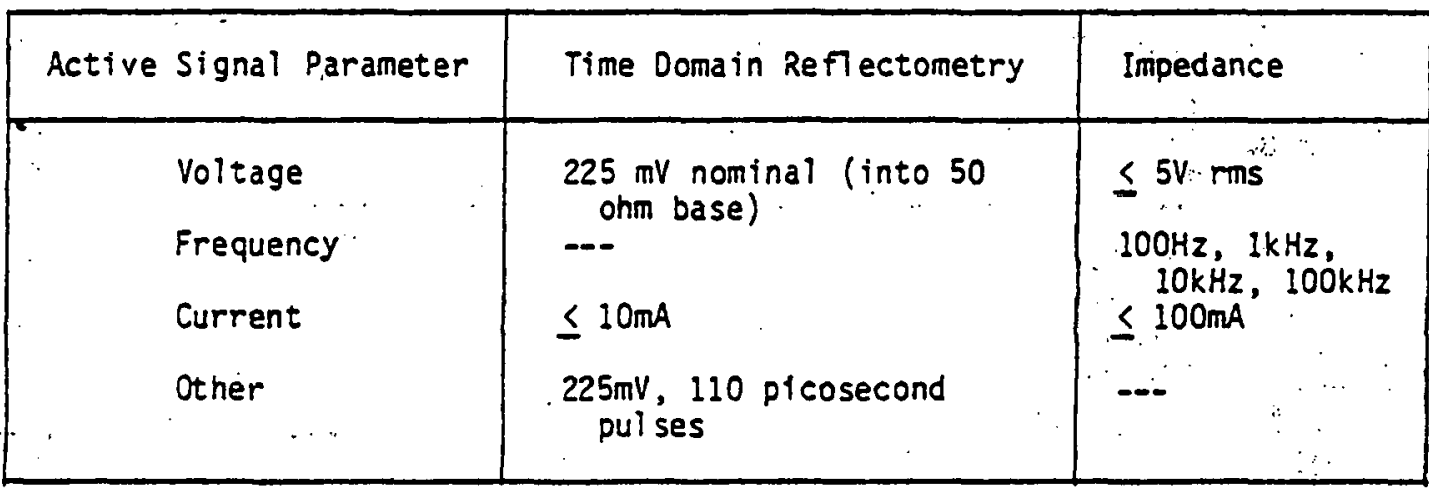

B. Prerequisites

1. The Shift Supervisor/Shift Foreman shall be notified for concurrence prior to the performance of those measurements.

2. Instrumentation personnel shall be asșigned to assist in the performance of these measurements.

3. All measuremients and test instrumentation shell be in current calibration (traceable to iNBS).

4. The Shift Supervisor/Shift Foreman shall be notified prior to starting and upon completion of the measurements.

C. Procedure for Performing Measurements

References:

I. Bailey Meter Company Transmitter $\frac{a}{\pi} B Y-8231 X-A$.

2. Bailey Product. Instruction E 21-17. 


\section{Page $A-6$}

IN-SITU MEASUREMENTS OF CABLES AND SIGNALS

NC. FROM CORE FLOOD TANK TANK LEVEL TRANSHITTER EY, 0

3. Burns \& Roe Dwg. 3343, Sh. 4.

4. Burns \& Roe Dwg. 3024, Sh. 20.

5. Burns \& Roe Owg. 3045, Sh. 36F.

6. Instruction Manual, Tektronix iodel 1502 Time Domain Reflectometer.

7. Instruction Manual, Hewlett Packard Hodel 4274 Multifrequency LCR . Meter.

8. Instruction Manual, Hewlett Packard Spectrum Analyzer (Model 141T, $85538,8552 B$ Modules).

9. Instruction Manual, Nicolet itodel 444A-25 Spectrum Analyzer.

10. Instruction Manual, Tektronix Model 335 Oscilloscope.

11. Instruction Manual, Lockheed Store-4 Recorder.

12. Instruction Manual, Tektronix SC502 Oscilloscope.

13. TEC Composite Electrical Connection Diagram, CF-2-LT4 (see attachment).

\begin{tabular}{|l|c|c|}
\hline \multicolumn{1}{|c|}{ SIGNAL } & CABLE & $\begin{array}{c}\text { CAB INET } \\
156\end{array}$ \\
\hline $\begin{array}{l}\text { Signal } \\
\text { - Signal }\end{array}$ & IT1730I & TB $8-9-3 / 19$ \\
IT1730I & TB $8-9-3 / 18$ \\
I18 VAC (H) & IT2751C (L) & TB $8-9-3 / 16$ \\
$\begin{array}{c}\text { Shield } \\
\text { (Signal) }\end{array}$ & IT275IC & TB $8-9-3 / 16$ \\
\hline
\end{tabular}

\section{STEPS}

1. Notify Shift Supervisor/Shift Foreman of start of test on CF-2-LT4.

2. Verify power is appl ied to CF-2-LT4.

3. Record present readings from $C F-2-L T 4$ Readout Module.

\section{3 of 11}


Page $A-7$

IN-SITU MEASUREMENTS OF CABLES AND SIGNALS
FROM CORE FLOOD TANK LEVEL RRANSMITTER
CF-2-LT4

NC.

TP-109

EY: $\cdots$

\begin{tabular}{|c|c|}
\hline SIGNAL & $\because$ LEVEL \\
\hline $\begin{array}{c}\text { CF-2-LT4 } \\
\text { Readout }\end{array}$ & $/ / / T T$. \\
\hline
\end{tabular}

3. Connect differential conditioning amplifier TEC Model ${ }_{n t}^{4} 901$ across TB 8-9-3/19 $(+)$ and $/ 18(-)$. Connect output from TEC Model $\frac{3}{\pi} 901$ to $F M$ Recorder and record - for 30 minutes.

4. Using a Keithley Model 177 DMM (or equivalent, Range $0-2000$ V. Precision $\pm 1 \%$ ) measure the $O C$ Voltage or current at the following test points.

\begin{tabular}{|c|c|c|c|}
\hline SIGIAL & CABINET 156 & TEST LEAD & READING \\
\hline a. & $\begin{array}{r}8-4-3 / 19 \\
\text { TB } 8-9-3 / 18\end{array}$ & $\begin{array}{l}(+) \\
(-)\end{array}$ & signal 5.719 voc \\
\hline b. & $\begin{array}{l}\text { TB } 8-9-3 / 16 \\
\text { TB } 8-9-3 / 17\end{array}$ & $(+)$ & 118 VAC $/ 16 . / l^{\prime} \not C$ \\
\hline
\end{tabular}

*CAUTION: 118 VAC

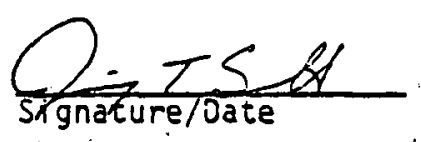

5. Using a Tektronix Model SC502 (or equivalent) osçilloscope observe the de-coupled waveform at the following test point.s: 
Page A-3

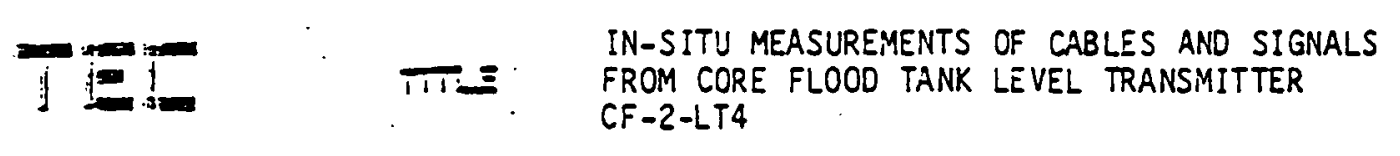

NAC TP-109

FEY, 0

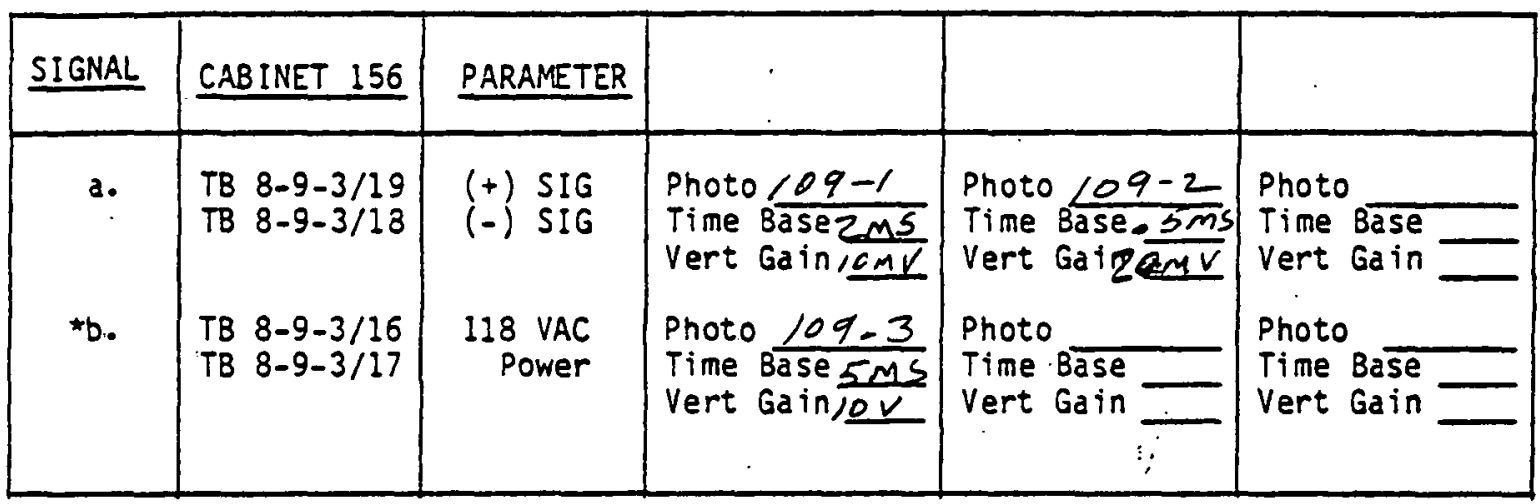

*CAUTION 118 VAC; USe $\times 10$ Probe.

Sync the oscilloscope and photograph the waveform using up to three time base and vertical gain settings. Mark the back of the photographs with the instrument tag number and parameter measured.

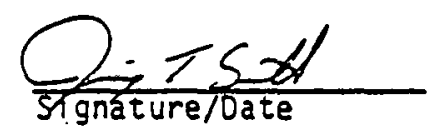

6. Using a Hewlett-Packard Spectrum Analyzer (Models $141 \mathrm{~T}, 8553 \mathrm{~B}$ and 2552 or equivalent) perform an analysis of the following signal for spectral content:

\begin{tabular}{|c|l|l|l|}
\hline SIGNAL $^{+}$ & CABINET 156 & PARAMETER & PHOTO \\
\hline a. & LP 8-9-3/19 & (+) SIG & $109-4$ \\
& TB $8-9-3 / 18$ & (-) SIG & $109-5$ \\
\hline
\end{tabular}

Before photographing each scope display adjust analyzer for best spectral resolution. Record critical anaiyzer parameters e.g., RF bandwidth, RF bandwidth and sweep speed on rear of photograph as well as parameter analyzed. 


$$
\begin{aligned}
& \begin{array}{l}
\text { IN-SITU MEASUREMENTS OF CABLES AND SIGAL } \\
\text { SPECTRUM IDENT } \\
\text { CFOM CORE FLOOLO TANK LEVEL TRANSMITTER }
\end{array}
\end{aligned}
$$

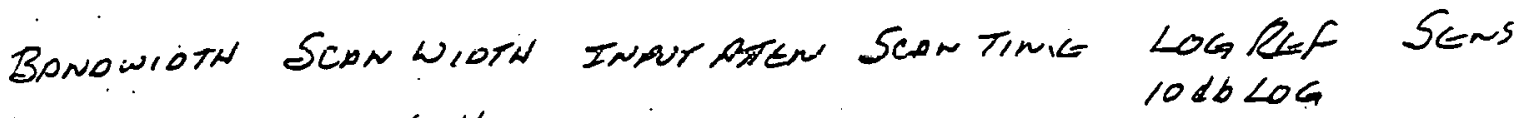

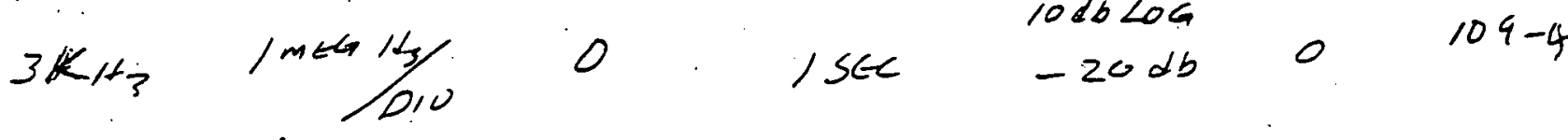

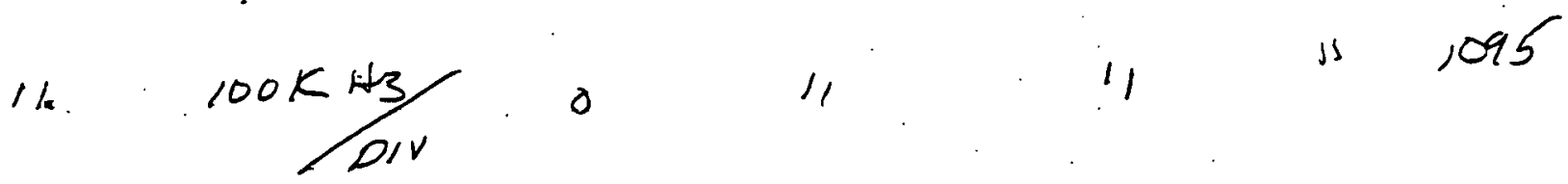

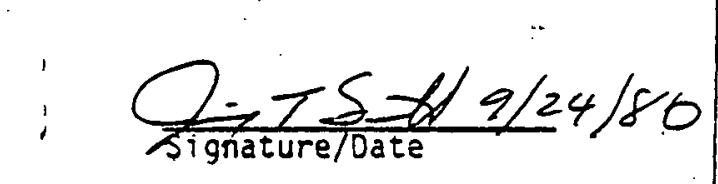

7. Using the Nicolet ilodel 444 FFT Analyzer (or equivalent) perform FFT annalysis of signals for the following test point:

\begin{tabular}{|c|c|c|c|c|}
\hline SIGNAL & CABINET 156 & PARAMETER & PHOTO \# & \\
\hline a. & $\begin{array}{ll}\text { TB } & 8-9-3 / 19 \\
\text { TB } 8-9-3 / 18\end{array}$ & $\begin{array}{ll}(+) & \text { SIG } \\
(-) & \text { SIG }\end{array}$ & $\begin{array}{l}109-6 \\
109-7\end{array}$ & $\begin{array}{l}\text { 100K RONGE } \\
1 \text { K RONGE }\end{array}$ \\
\hline
\end{tabular}

3. Inside Cabinet 156 perform usual electronic calibrations using applicable instrument shop procedures. Attach instrument shop calibration data sheet and record any significant adjustments or problems in the space below. 


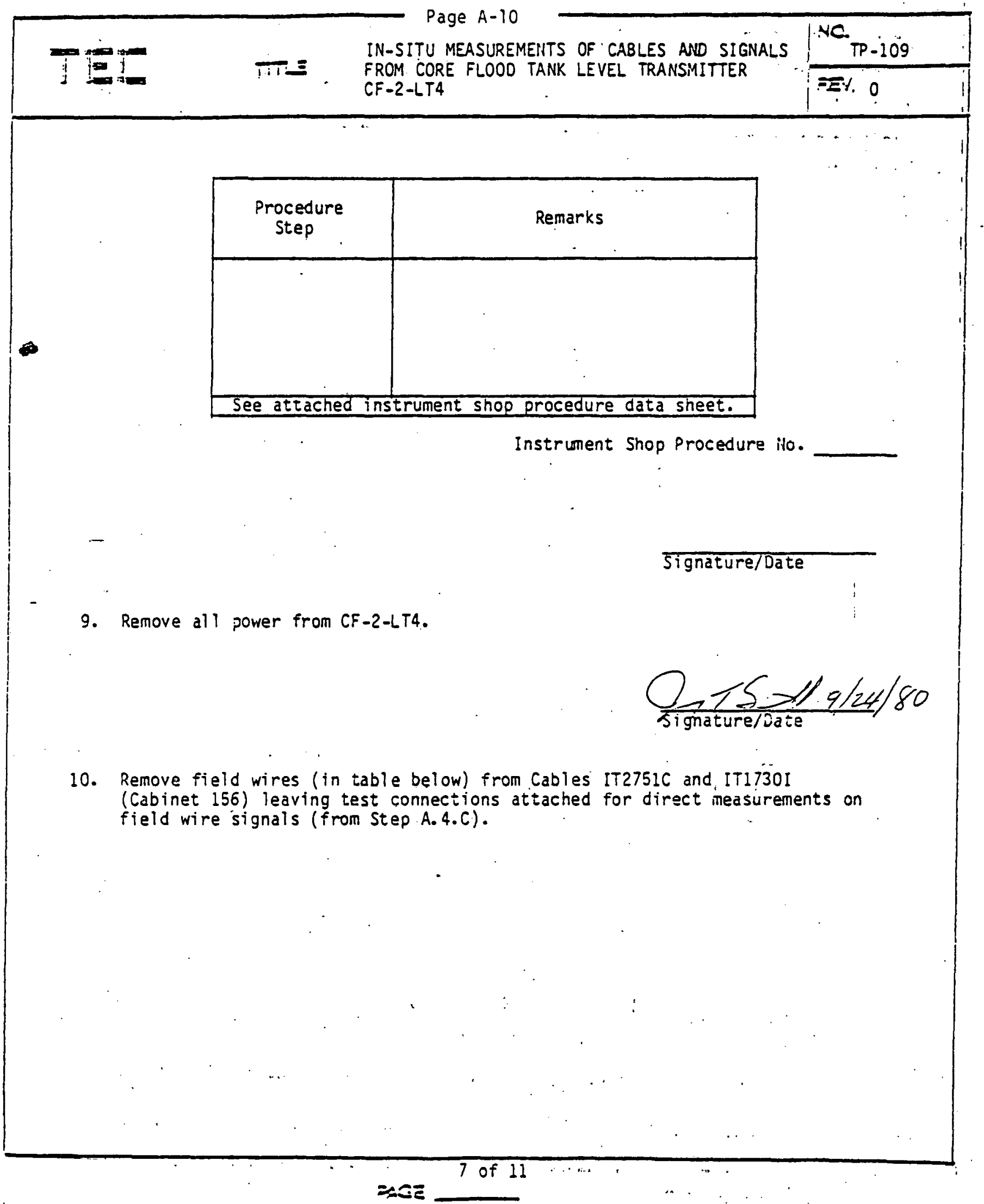


Page $\hat{n}-11$

IN-SITU MEASUREMENTS OF CABLES AND SIGNALS NC TP-109 Ti= FROM CORE FLOOD TANK LEVEL TRANSMITTER CF - 2-LT4

EY. 0

\begin{tabular}{|l|l|}
\hline CABINET 156 & SIGNAL IDENT. \\
\hline TB 8-9-3/19 & (+) SIGNAL \\
TB $8-9-3 / 18$ & (-) SIGNAL \\
TB 8-9-3/16 & (H) 118 VAC \\
TB 8-9-3/17 & (L) 118 VAC \\
TB 8-9-3/20 & SHIELD (Signal) \\
\hline
\end{tabular}

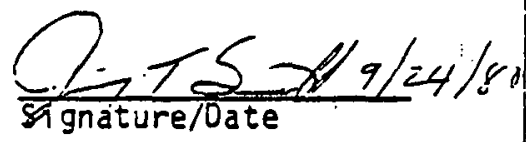

11. Using the Hewlett-Packard Hodel 4274 (or equivalent) Impedance Bridge; measure the capacitance and impedance at the following test points:

\begin{tabular}{|c|c|c|}
\hline TEST POINT & FROM & TO \\
\hline a. & TB $8-9-3 / 19$ (+) Signal & TB 8-9-3/18 (-) Signal \\
b. & TB $8-9-3 / 19$ (+) Signal & TB 8-9-3/20 Shield (Signal) \\
c.. & TB 8-9-3/18 (-) Signal & TB 8-9-3/20 Shield (Signal) \\
d. & TB 8-9-3/16 118 VAC (H) & TB 8-9-3/17 118 VAC (L) \\
e. & TB 8-9-3/16 118 VAC (H) & TB 8-9-3/19 (+) Signal \\
f. & TB 8-9-3/16 118 VAC (H) & TB 8-9-3/18 (-) Signal. \\
g. & TB 8-9-3/16 118 VAC (H) & TB 8-9-3/20 Shield (Signal) \\
\hline
\end{tabular}




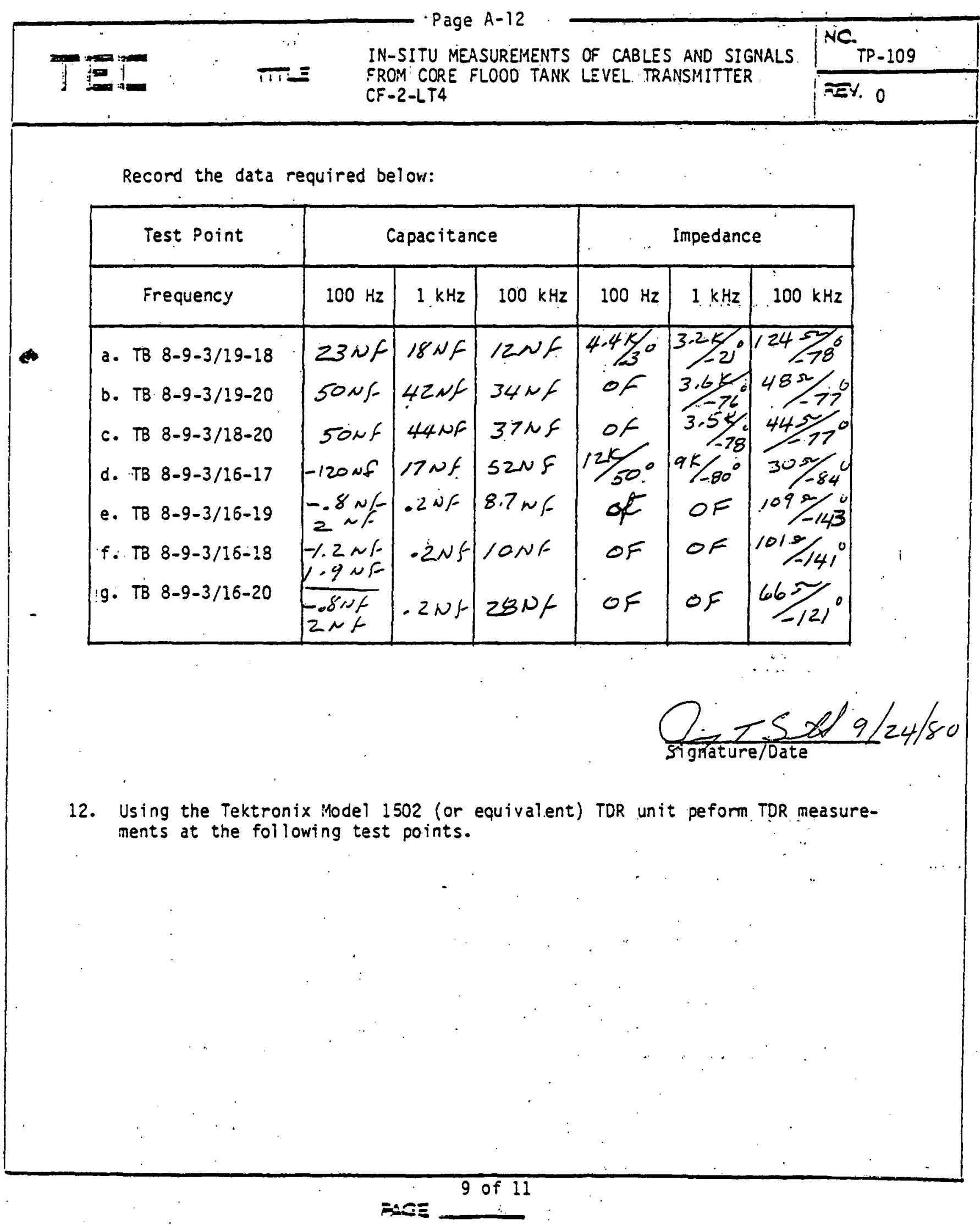




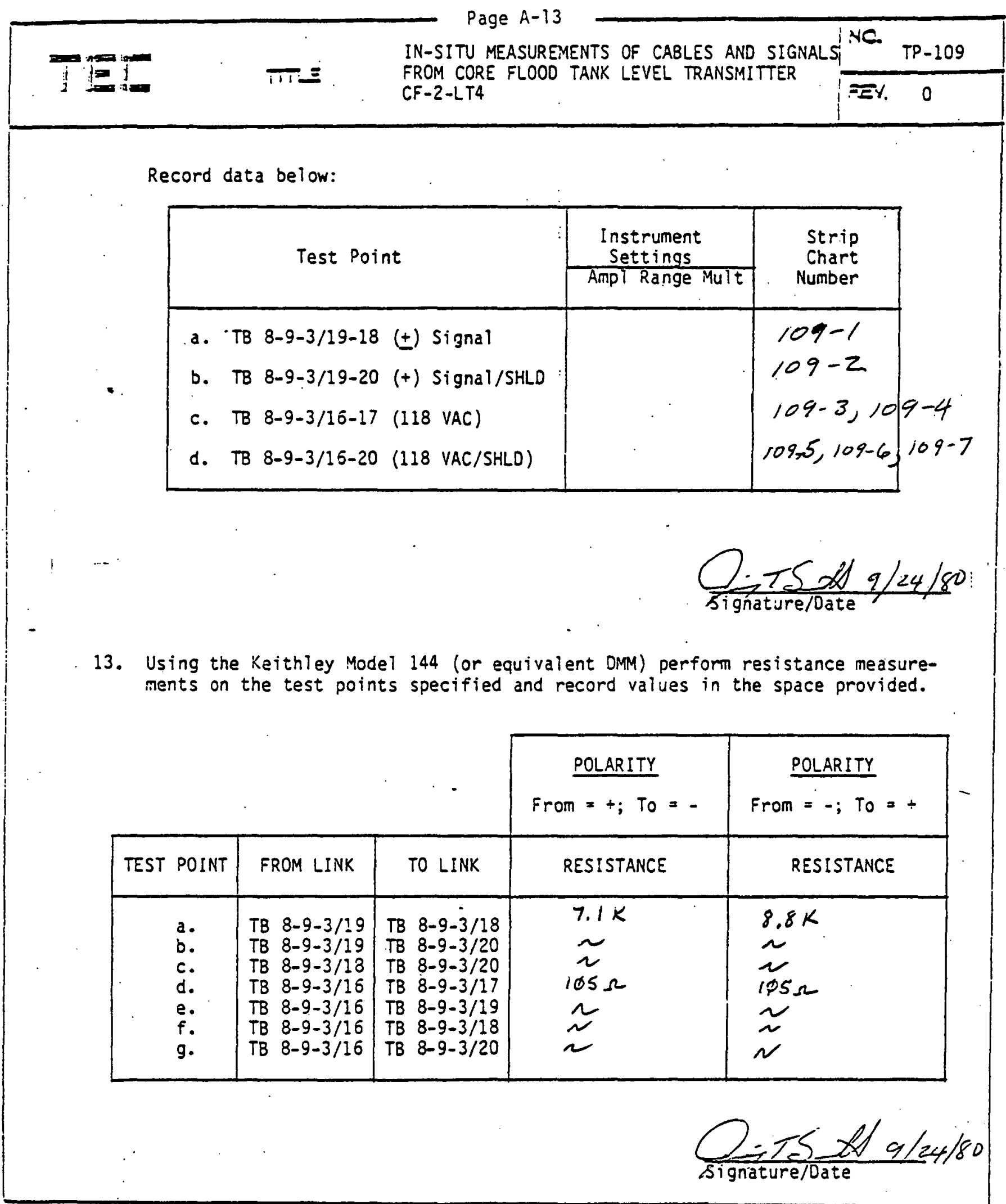




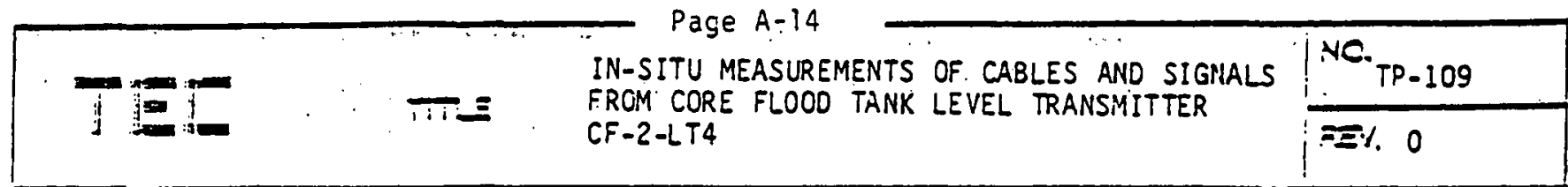

14. Connect field wires from Cables IT2751C and ITI730I at Cabinet 156 (see Step 10) and apply power.

15. Notify the Shift Supervisor/Shift Foreman of the conclusion of testing CF-2-LT4.

I hereby certify that this Test Procedure has been completed as written and that all data has been correctily entered and filed as requested:

TEC Representative

signature/Date

Instrumentation

Signature/0ate 


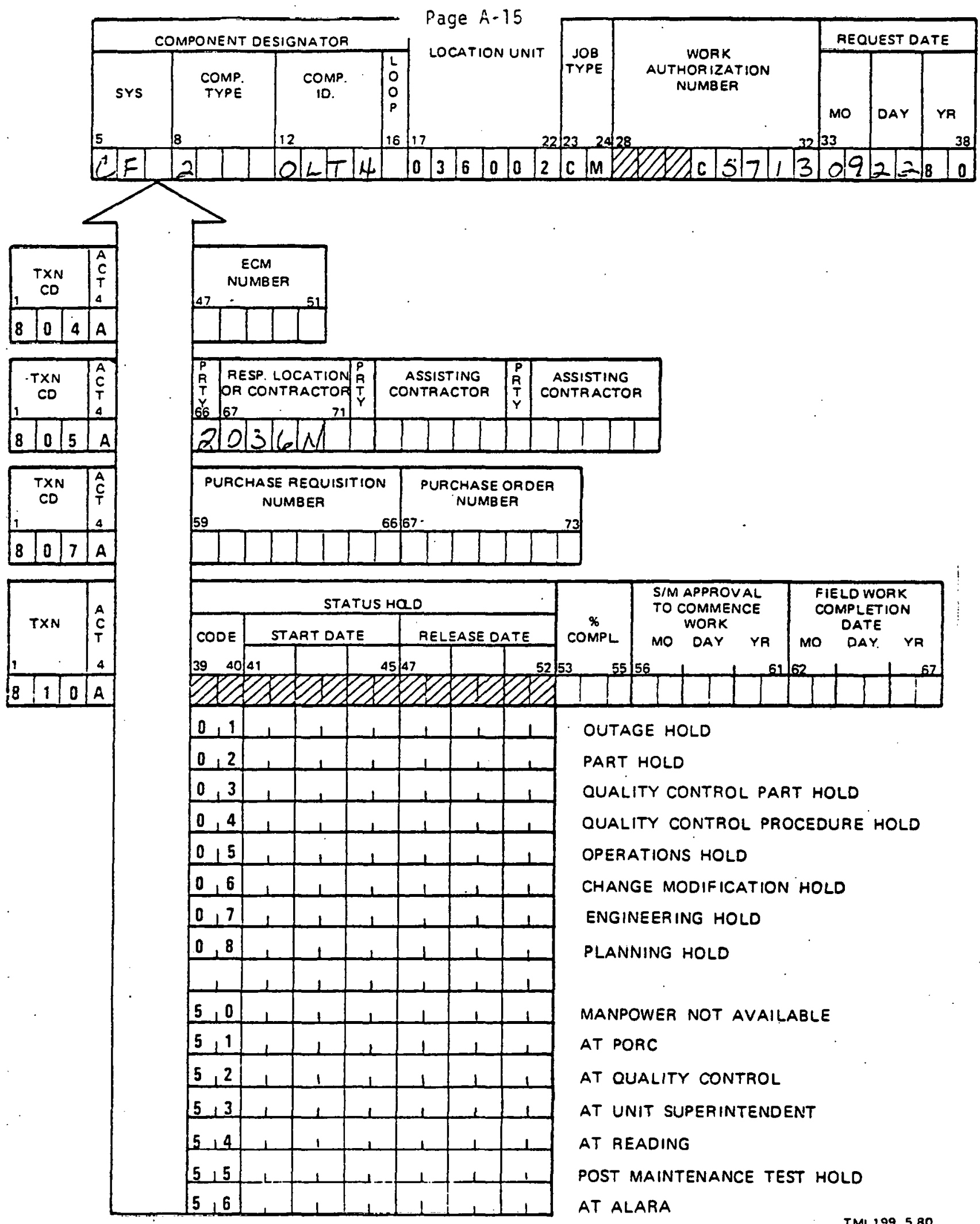

